\title{
Comparative study on the Anuran Communities (Amphibia Anura) in Agusan Marsh Wildlife Sanctuary, Philippines
}

\author{
Richel E. Relox ${ }^{1,2 *}$ \& Fritzie A. Camino²
}

${ }^{1}$ Department of Environmental Science and Technology, College of Science and Mathematics, University of Science and Technology of Southern Philippines, Cagayan de Oro City, Philippines

${ }^{2}$ Department of Biological Sciences and Environmental Studies, College of Science and Mathematics, University of the Philippines in Mindanao, Mintal, 8000 Davao City, Mindanao, Philippines

"Corresponding author, e-mail: chelox_8224@yahoo.com

ABSTRACT

The Agusan Marsh Wildlife Sanctuary harbors numerous species of Anurans (Amphibia Anura) that have highly threatened habitats. The species of anurans were observed in different vegetation types such as Terminalia forest, sago palms, and rice fields in the Agusan Marsh Wildlife Sanctuary, Bunawan, Agusan del Sur on May and October 2008. Result showed abundant, diverse, endemic, and threatened anuran species. Nine species of frogs with 148 individuals were documented. The sago forest had the highest anuran population with 76 inviduals ( 3 species) followed by 41 ( 5 species) in the Terminalia forest and 31 ( 3 species) in the agricultural areas adjacent to sago stands. Of these, $66.7 \%$ are Philippine endemics. However, the remaining $33.3 \%$ are threatened by natural habitat conversion. Naturally grown sago stands are ultimately a habitat for several anurans found only in the Philippine archipelago. $O$. laevis and L. leytensis are identified as sago forest indicators. Indeed, their absence or decline in population over time may have detrimental impact on the survival of the sago stands in the Agusan wetlands. The anuran species are highly habitat specific. Indeed, sago stands harbor endemic and unique anuran species that need to be conserved and protected.

KEY WORDS Agusan marsh; amphibians; biodiversity; conservation; protection.

Received 27.07.2018; accepted 17.08.2018; printed 30.09.2018; published online 05.09.2018

\section{INTRODUCTION}

The Philippines has diverse flora and fauna but are now highly threatened by human activities. To date, the country has a high percentage of amphibian endemism (more than 50\%) compared to other groups of wildlife such as mammals, birds, and reptiles. Currently, an estimate of 105 species are present in the Philippines, which may increase to 160 species considering future conservation studies on evolutionary diversification using morphological characteristics, genetic data, and mating calls (Brown et al., 2008). Therefore, there is no doubt about future discoveries of new species in the Philippines in addition to the present count (Taylor, 1923, 1925 as cited by Brown \& Gonzalez, 2007).

One of the protected areas in the country, the Agusan Marsh Wildlife Sanctuary, harbors unique species of wildlife. This wetland is characterized by extensive floodplains and shallow lakes that shrink and partially dry up from April to October and flood from November to late March (RAMSAR, 2003). It is important not only because of its many ecolog- 
ical functions, from providing habitats to wildlife, water cycling and carbon sequestration, to regulating local climate, but also of its economic importance to local communities. Not only it holds undiscovered and potentially important species, but it is also the temporary home of migratory birds from temperate regions.

The marsh has different habitat types, such as the Philippines' largest Terminalia forest, dominated by T. copelandii (Frazier, 1999). This type of forest is an important source of high value timber and other non-wood forest products. Another vegetation type is sago palms, which are interspersed and scattered through the forest. Metroxylon sagu Rottb., known as sago, serves as a staple food for indigenous people in the area during the wet season or when there arefloods as substitute for rice (Flach, 1997). Ecologically, swamps and wetlands, home to the sago palms, are among the richest biomes. Sago palms grow in Mindanao and Visayas dry portions, unlike in the Agusan wetlands. Sago palms grow individually or in dense clumps (Mason, 2000 as cited by Palafox, 2006) and are distributed along Southeast Asia, South Pacific, and South America. However, most of the Terminalia forest and the sago palm areas are converted for agricultural production, especially to rice fields, thus threatening the natural habitats of the fauna. As biological indicators of the health of the environment, anurans can be a gauge for disturbed and undisturbed sites since they have a wide range of habitats. Some species are highly sensitive to environmental changes, while others are more tolerant to disturbances.

In addition, anurans have a broader range of habitat preferences. By comparing upland studies to other parts of Mindanao (Mt. Hamiguitan Wildlife Sanctuary, Davao Oriental), and other studies in Lake Sebu, South Cotabato, there is still an observable high endemism and a certain diversity of amphibians (Ates et al., 2008; Rovillos et al., 2008). They are highly specific and diversified $(D=3.66)$ in aquatic habitats with wide distribution in lowland vegetation. More than $70 \%$ of the endemism occurred in Mt. Hamiguitan. Few of these endemic species were threatened. Around 16 species were also counted in Lake Sebu with four families. Unsustainable agricultural practices and other anthropological disturbances harm water bodies and low vegetation in Lake Sebu.
Another study in the mountainous areas in Mt. Sambilikan found and recorded 21 species belonging to four families, of which $12(57 \%)$ are endemics, while 8 were threatened (Fabricante \& Nuñeza, 2008). Habitat loss, wildlife hunting, and forest conversion continue to be local threats to their survival.

Thus, this study aimed to determine the recent species composition, diversity, and richness, as well as the endemisms and current threats for anurans, with reference to three types of vegetation such as the Terminalia forest, the sago stands, and the agricultural area in marginal habitats of the Agusan wetlands. The purpose was primarily to examine the role of the sago palms as a key habitat for anuran species and observe the pattern of anuran communities along with habitat modifications.

\section{MATERIAL AND METHODS}

\section{Habitat Characterization}

The fieldwork was conducted in three selected types of vegetation and habitat utilized by amphibians: the Terminalia forest, the sago stands, and the agricultural area of the Agusan Marsh Wildlife Sanctuary located at $8^{0} 19^{\prime} 0^{\prime}$ N - $125^{\circ} 52^{\prime} 0^{\prime \prime}$ E (Figs. 1-4). A total of eight sampling sites composed of five sites in the sago forest with the adjacent agricultural areas and three sites of the Terminalia forest in Kaliloan, Bunawan, and Agusan del Sur were carried out on May and October 2008.

These identified areas have different vegetation. Some were old-growth forest of Terminalia, while other areas have sago stands and the other portion of the site is filled with rice fields. They appeared as patches, ranging from 0.5 ha. to more than 50 ha. and serving as buffer zones of the Agusan marsh. The first, second, and fifth sites were smaller patches, while the third and fourth sites were larger patches. However, the sites were disturbed due to slash and burn practices encroaching and converting the Terminalia and the sago forests into rice fields. The vegetation associated to the sago stands are dominated by large trees, vines, epiphytes, and thick humus cover. The sixth site is connected to a large timberland, while the seventh site is a large patch of the Terminalia forest and 
other woody trees. Wildlife hunting, clearings, and slash and burn practices are prevalent threats in the eight site of the Terminalia forest. This area is adjacent to the sixth site at the border with the Agusan marsh.

\section{Anuran Survey and Its Efficiency}

A 100 meters transect line was established from the edge to the interior of each habitat type, such as the Terminalia forest, sago stands, and rice fields. Direct counts of amphibians through visual encounter technique and opportunistic sampling along the line transects were used to sample amphibians. Sampling was done from $1800 \mathrm{~h}$ to $2200 \mathrm{~h}$ per night, from May 10 to 20 and from September 24 to October 1, 2008. Transect studies were conducted during periods with the greatest animal activity, especially during the night. The first major fieldwork began in the sago forest, followed by the agricultural area and the Terminalia forest. In these sites, flooded forest floor, palm foliage, and other low-lying vegetation were extensively searched for possible amphibian inhabitants.

Frogs were collected using bare hands in each microhabitat and placed in plastic containers. Morphometrics such as snout to vent length (SVL), head length (HdL), hind limb length (HL), forelimb length (FL), and tibia length (TbL) were measured using a vernier caliper. Distinguishing morphological characteristics were also noted and compared to the descriptive data of the Philippine frogs by Alcala (1982). Man-hours were calculated by multiplying the number of collectors and the number of hours spent searching for frogs in
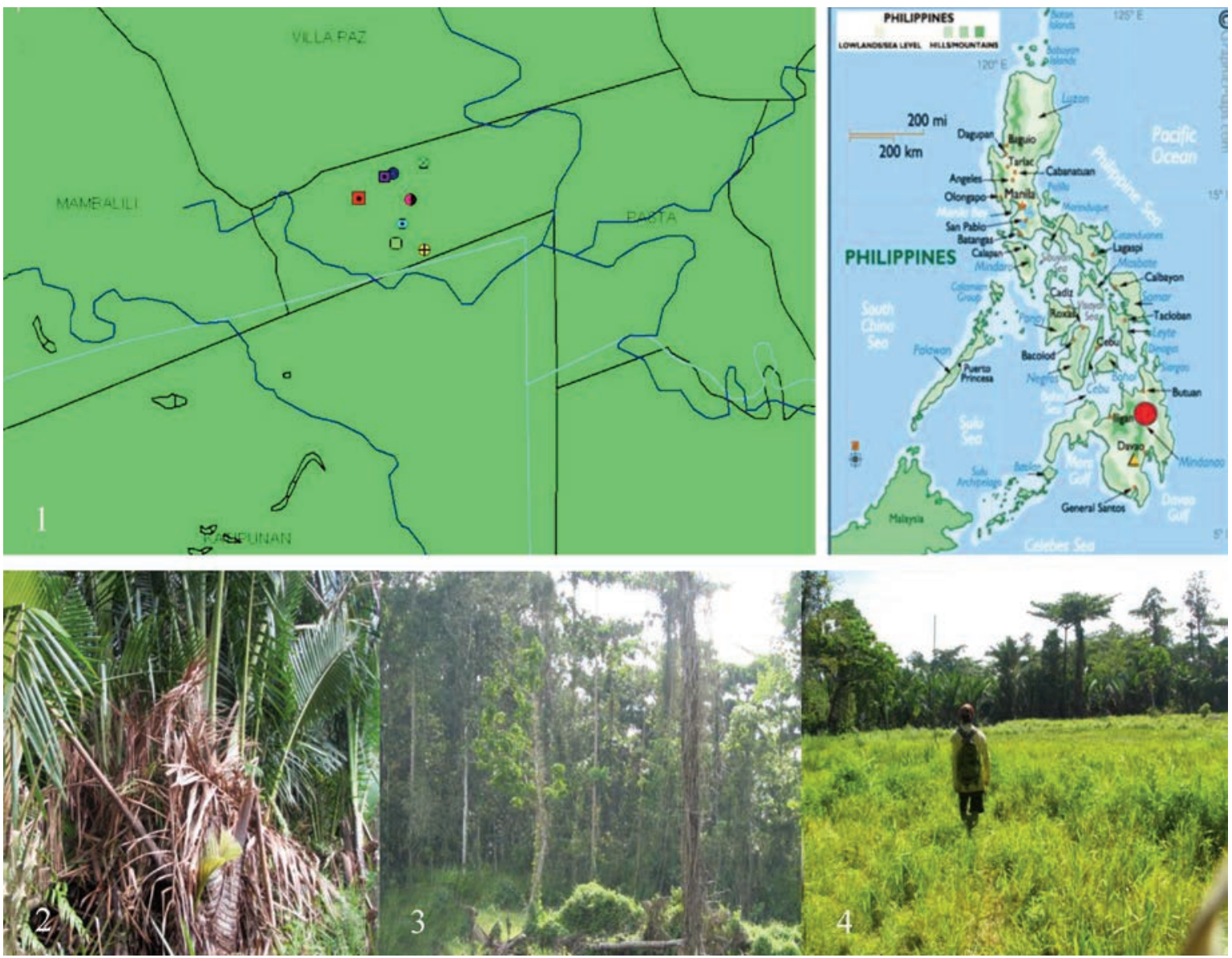

Figures 1-4. Map of the Philippines and location of the eight sampling points in Agusan marsh (Fig. 1) characterized by three vegetation types such as: Fig. 2: sago stands in water-logged areas. Fig. 3: Terminalia forest. Fig. 4: ricefield, Bunawan, Agusan del Sur, Mindanao Island. 
each site. Initial records showed six anuran species in the sago forest and its neighboring habitats, documented in 10 man-hours. This number increased to seven species in 17.5 man-hours and climbed up to nine species after 27.5 manhours. Thereafter, the number of species remained stable up to the last sampling efforts provided. There was definitely a sufficient sampling effort provided in varied vegetative cover in the Agusan marsh.

The number of amphibians for every man-hour in each habitat is used to estimate occurrence and relative abundance of the species. Philippine endemic species and threatened ones were also counted and analyzed. Current conservation status based on the International Union for the Conservation of Nature (IUCN, 2017) was determined for each species. Geographic distribution was digitally mapped for future monitoring purposes of the sago areas and its associated vegetation as their habitats. Simpson's and Shannon-Weaver's diversity indices, richness, evenness and Jaccard's similarity coefficient were calculated to assess the status of the Agusan marsh.

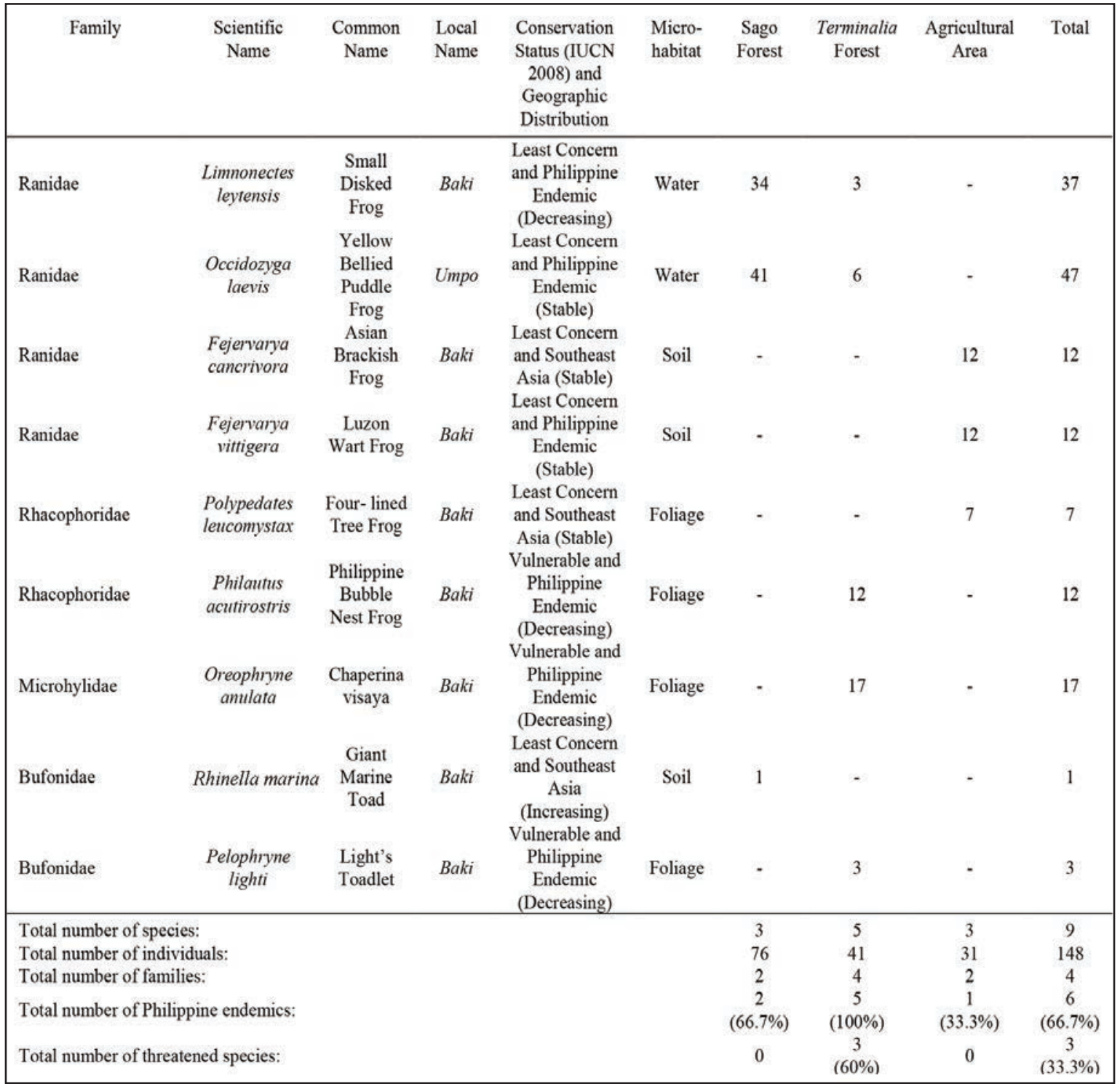

Table 1. Anuran species inhabiting Agusan marsh, Bunawan, Agusan del Sur, Mindanao, Philippines. 


\begin{tabular}{|c|c|c|c|c|c|c|c|}
\hline Scientific Name & Population & $\begin{array}{l}\text { Snout to vent } \\
\text { length (SV) } \\
(\mathrm{mm})\end{array}$ & $\begin{array}{l}\text { Head length } \\
\text { (HdL) } \\
(\mathrm{mm})\end{array}$ & $\begin{array}{c}\text { Hindlimb } \\
\text { length }(\mathrm{HL}) \\
(\mathrm{mm})\end{array}$ & $\begin{array}{l}\text { Forelimb } \\
\text { length (FL) } \\
(\mathrm{mm})\end{array}$ & $\begin{array}{l}\text { Tibia length } \\
\text { (TbL) } \\
\text { (mm) }\end{array}$ & $\begin{array}{c}\text { Most Distinguishing } \\
\text { Characters }\end{array}$ \\
\hline $\begin{array}{l}\text { Limnonectes } \\
\text { leytensis }\end{array}$ & 37 & $34.4 \pm 10.1$ & $13.1 \pm 12.7$ & $50.9 \pm 14.4$ & $16.2 \pm 5.6$ & $17.3 \pm 8.1$ & $\begin{array}{l}\text { Inverted V mark on } \\
\text { dorsal side }\end{array}$ \\
\hline Occidozyga laevis & 47 & $33.5 \pm 6.2$ & $9.8 \pm 3.5$ & $43.4 \pm 7.6$ & $12.4 \pm 3.9$ & $12.7 \pm 3.3$ & $\begin{array}{l}\text { Short legs; with or } \\
\text { without middorsal line }\end{array}$ \\
\hline $\begin{array}{l}\text { Fejervarya } \\
\text { cancrivora }\end{array}$ & 12 & $55.3 \pm 10$ & $18.2 \pm 4.2$ & $85.9 \pm 21.6$ & $23.8 \pm 5.8$ & $29.1 \pm 7.1$ & $\begin{array}{l}\text { Smooth dorsal side; } \\
\text { stout bodied }\end{array}$ \\
\hline $\begin{array}{l}\text { Fejervarya } \\
\text { vittigera }\end{array}$ & 12 & $56.1 \pm 15.5$ & $18.8 \pm 5.9$ & $78.9 \pm 28.5$ & $25.3 \pm 7.6$ & $27.9 \pm 8.7$ & $\begin{array}{l}\text { Rough dorsal } \\
\text { markings; big body }\end{array}$ \\
\hline $\begin{array}{l}\text { Polypedates } \\
\text { lencomystax }\end{array}$ & 7 & $47.1 \pm 3.7$ & $14.6 \pm 2.8$ & $70.4 \pm 7.8$ & $19.1 \pm 6.9$ & $22.6 \pm 4.7$ & $\begin{array}{l}\text { Long legs; large } \\
\text { slender body }\end{array}$ \\
\hline $\begin{array}{c}\text { Philautus } \\
\text { acutirostris }\end{array}$ & 12 & $19.8 \pm 2.0$ & $8.6 \pm 1.9$ & $32.5 \pm 3.1$ & $9.7 \pm 2.2$ & $11.6 \pm 2.0$ & $\begin{array}{l}\text { Short, long legs; } \\
\text { arboreal }\end{array}$ \\
\hline $\begin{array}{c}\text { Oreophryne } \\
\text { amulata }\end{array}$ & 17 & $12.5 \pm 3.9$ & $4.2 \pm 3$ & $19.4 \pm 4.3$ & $5.7 \pm 2.9$ & $5.8 \pm 3.2$ & $\begin{array}{l}\text { Short, slender bodies; } \\
\text { arboreal }\end{array}$ \\
\hline Rhinella marina & 1 & 100.0 & 28.0 & 95.0 & 60.0 & 37.0 & $\begin{array}{l}\text { Warty frog; exotic; } \\
\text { poisonous }\end{array}$ \\
\hline Pelophryne lighti & 3 & $9.3 \pm 1.5$ & 1.0 & $15.3 \pm 3.1$ & $1.9 \pm 1.7$ & $1.2 \pm 0.8$ & $\begin{array}{l}\text { Short, slender body; } \\
\text { light middorsal line }\end{array}$ \\
\hline
\end{tabular}

Table 2. Morphometric data and phenotypic characters used to identify anuran species in the sago forest and its environs, Agusan marsh, Kaliloan, Bunawan, Agusan del Sur.

\begin{tabular}{|c|c|c|c|c|}
\hline Biodiversity Measurements & Sago Forest & $\begin{array}{r}\text { Terminalia } \\
\text { Forest }\end{array}$ & $\begin{array}{r}\text { Agricultural } \\
\text { Area }\end{array}$ & $\begin{array}{c}\text { Agusan } \\
\text { Mars } \\
\text { h } \\
\end{array}$ \\
\hline Species Richness (d) & 3.8 & 3.2 & 3.0 & 1.7 \\
\hline Simpson's Diversity Index $\left(D_{s}\right)$ & $0.5 \pm 0.11$ & $0.7 \pm 0.06$ & $0.6 \pm 0.06$ & $0.8 \pm 0.035$ \\
\hline $\begin{array}{l}\text { Shannon-Weaver's Diversity Index } \\
\left(\mathrm{H}^{\prime}\right)\end{array}$ & $1.1 \pm 0.22$ & $2.0 \pm 0.23$ & $1.5 \pm 0.026$ & 2.60 \\
\hline $\begin{array}{l}\text { Evenness of Shannon-Weaver's } \\
\left.\text { Index ( } \mathrm{J}^{\prime}\right)\end{array}$ & 0.7 & 0.9 & 3.2 & 0.9 \\
\hline Evenness of Simpson's Index $\left(E_{s}\right)$ & 0.8 & 0.9 & 1.0 & 0.8 \\
\hline $\begin{array}{l}\text { Jaccard's Similarity Coefficient } \\
\text { (CCj) }\end{array}$ & $\begin{array}{c}\text { Sago palms } \\
\text { and } \\
\text { Terminalia } \\
(0.33)\end{array}$ & $\begin{array}{c}\text { Terminalia and } \\
\text { Agricultural } \\
\text { area } \\
(0)\end{array}$ & $\begin{array}{c}\text { Sago palms } \\
\text { and } \\
\text { Agricultural } \\
\text { area } \\
(0)\end{array}$ & \\
\hline
\end{tabular}

Table 2. Biodiversity measurements of anuran communities in Agusan wetlands, Bunawan, Agusan del Sur, Mindanao, Philippines. 


\section{RESULTS AND DISCUSSIONS}

\section{Species Composition and Abundance of Anu- rans in the Agusan Marsh}

The number of captured amphibian species in the sago forest as well as in the adjacent Terminalia forest and the agricultural area in the marshland of Agusan reached 148 individuals with nine species assigned to four families: Ranidae, Rhacophoridae, Microhylidae, and Bufonidae (Table 1). Among them, there are the Limnonectes leytensis (Boettger, 1893), Occidozyga laevis (Günther, 1858), Polypedates leucomystax (Gravenhorst, 1829), Philautus acutirostris (Peters, 1867), Fejervarya cancrivora (Gravenhorst, 1829), Oreophryne anulata (Stejneger, 1908), Rhinella marina (Linnaeus, 1758), Pelophryne lighti (Taylor, 1920), and Fejervarya vittigera (Wiegmann, 1835). Previously, only three families of anurans such as Ranidae, Rhacophoridae, and Microhylidae which included eight species such as Fejervarya cancrivora, Pulchrana grandocula (Taylor, 1920), Rana parva Taylor, 1920, Occidozyga laevis, Platymantis dorsalis (Duméril, 1853), Polypedates leucomystax, Philautus acutirostris, and Kaloula conjuncta (Peters, 1863) were recorded (Cabelin, 2007). Other species found in the Agusan marsh were Pulchrana grandocula, Polypedates leucomystax, Kaloula conjuncta, and Occidozyga laevis (Palafox, 2006).

The most abundant species of amphibians is $O c$ cidozyga laevis (47), followed by Limnonectes leytensis (37), Oreophryne anulata (17), Fejervarya cancrivora, Philautus acutirostris, and Fejervarya vittigera (12), Polypedates leucomystax (7), and Rhinella marina (1) (Figs. 5-10). The highest number of anurans is found in the sago stands (76) with three species such as Occidozyga laevis (41), Limnonectes leytensis (34), and Rhinella marina (1). This is followed by the Terminalia forest (41) with a slightly higher number of species (5) such as Pelophryne lighti (3), Oreophryne anulata (12), Philautus acutirostris (17), Occidozyga laevis (6), and Limnonectes leytensis (3). The agricultural area is preferred by three species of anurans, namely: Fejervarya vittigera (12), F. cancrivora (12), and Polypedates leucomystax (7), with a total of 31 individuals (Fig. 11).
The nine species of anurans in the sago forest and its associated vegetation varies in morphological measurements (Table 2). Based on the measured body lengths, the biggest in size relative to other species are Rhinella marina and Fejervarya vittigera, followed by Fejervarya cancrivora, Polypedates leucomystax, Limnonectes leytensis, Occidozyga laevis, Philautus acutirostris, Oreophryne anulata, while the smallest is Pelophryne lighti. They vary highly in morphological characteristics like the possession of rough or smooth dorsum, short and long legs, poison glands, and dorsal markings. These are all influenced by the type of life of the anurans in freshwater, terrestrial, and arboreal microhabitats.

\section{Microhabitats and Species Diversity of Anu- rans in the Agusan Marsh}

The number of aquatic and arboreal species is generally greater in the Agusan marsh (Fig. 12). In the Terminalia forest, arboreal species were more abundant than aquatic and terrestrial species. Meanwhile, aquatic species were more in sago stands compared to the terrestrial inhabitants. More terrestrial species dwell in the agricultural areas compared to the sago and Terminalia forests. Most Occidozyga laevis, Limnonectes leytensis, Fejervarya vittigera, and Fejervarya cancrivora highly preferred the waterlogged habitat of the sago forest and the adjacent agricultural area rather than the Terminalia forest. Soil availability and a stable amount of water support the survival and reproduction of frogs. Tree frogs such as Philautus acutirostris, Pelophryne lighti, and Oreophryne anulata live in the Terminalia forest, reaching up to more than 18 meters high and they are mainly situated in the sago forest. These species reside among the leaves and branches of tall grasses and trees. Polypedates leucomystax and Rhinella marina instead are considered as biological indicators of habitat disturbance in the marsh. The rise of their population number is an output of the highest disturbance level occurring in the forests.

The species richness of frogs in the Agusan marsh is $\mathrm{d}=1.68$ (Table 3 ). Amphibian diversity values are $\mathrm{Ds}=0.801 \quad\left(\mathrm{~J}^{\prime}=0.9\right)$ and $\mathrm{H}^{\prime}=2.637$ $(E S=0.83)$ using Simpson's and Shannon-Weaver's diversity indices, respectively. There is a higher anuran diversity in this study $\left(\mathrm{H}^{\prime}=1.464\right)$ compared 
to Cabelin (2007). The sago forest (3.8) had relatively rich amphibian species compared to the Terminalia (3.23) and agricultural area (2.99). The Terminalia forest (Ds=0.71, Es=0.89) adjacent to the sago stands had significantly higher amphibian diversity (Ds) followed by the agricultural area (Ds=0.65, Es=0.97) and the sago forest (Ds=0.51, Es=0.76). Using Shannon-Weaver's diversity index, the Terminalia forest had consistently the greatest diversity of amphibians $\left(\mathrm{H}^{\prime}=2.00, \mathrm{~J}^{\prime}=0.86\right)$ compared to the agricultural area $\left(\mathrm{H}^{\prime}=1.54\right.$, $\left.\mathrm{J}^{\prime}=3.24\right)$ and the sago forest $\left(\mathrm{H}^{\prime}=1.08, \mathrm{~J}^{\prime}=0.68\right)$. The sago stands served as an alternative habitat for most amphibian species in the Agusan marsh, since these areas are also almost immersed in water throughout the year, similarly to the Terminalia forest. However, some of the water from the forest flow to the rice fields endangering the habitat of frogs.

The composition of anurans between the sago and the Terminalia forests $(\mathrm{CCj}=0.33)$ is highly similar. On the contrary, such composition is much more dissimilar between the Terminalia and the agricultural area and the sago forest and the agricultural field. This finding implicates that the sago stands have a greater role in maintaining the diversity of anurans in the Agusan wetlands as a whole. Anurans are highly dependent to the sago forest and the timberland. They specialized more on the available food resources such as insects (Hymenopterans, Hemipterans and Orthopterans), foliage, seed, amphibian tadpole, and fish (Palafox, 2006).

\section{Endemicity and Conservation Status of Anu- rans in the Agusan Marsh}

In the Agusan wetlands, Philippines endemic frogs are more abundant $(66.7 \%)$ than non-endemics (Fig. 13). The Terminalia forest has the highest endemism, followed by the sago forest and rice fields.

Endemics are abundant in areas with less disturbed vegetation. Naturally grown sago palms and Terminalia trees in water-logged areas are preferred by anurans. Mindanao endemics are ab-
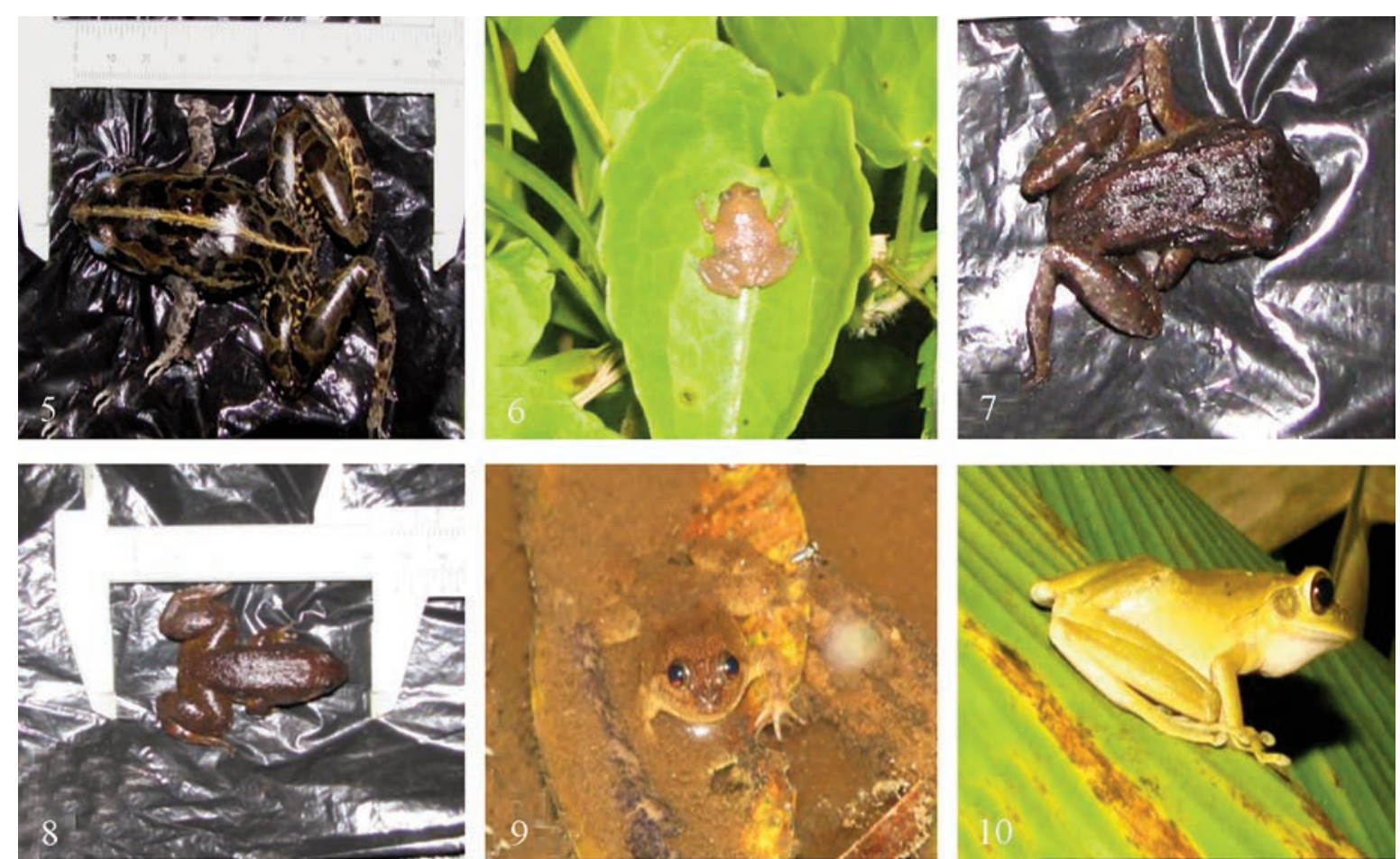

Figures 5-10. Anuran species found in Agusan marsh, Bunawan, Agusan del Sur, Mindanao. Fig. 5: Fejervarya cancrivora. Fig. 6: Oreophryne anulata. Fig. 7: Limnonectes leytensis. Fig. 8: Occidozyga laevis. Fig. 9: Fejervarya vittigera. Fig. 10: Polypedates leucomystax. 


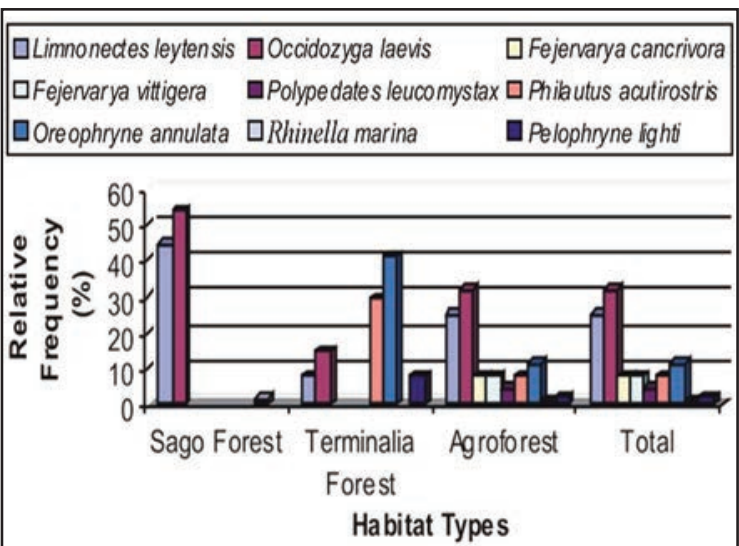

Figure 11. Relative frequency (\%) of anurans in three kinds of habitat in Agusan wetlands, Bunawan, Agusan del Sur, Mindanao, Philippines.

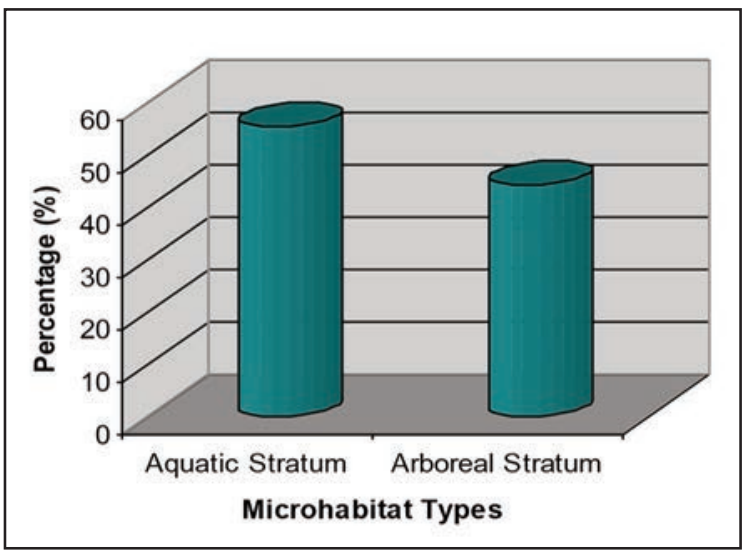

Figure 12. Microhabitat preference (\%) of amphibian species documented in sago forest and its associated vegetation in Agusan wetlands, Kaliloan, Bunawan, Agusan del Sur.

sent in this wetland. Conversely, non-endemics predominated the cultivated areas like the rice fields. They proliferate and survive in disturbed habitats.

Threatened species accounted for $33.3 \%$ since their habitats have been exploited by slash and burn practices and some of them served as subsistence for human consumption (Fig. 14). In the Terminalia forest, rather than sago forest and agricultural areas, threatened species are more abundant than non-threatened ones. This record may be attributed to a bigger habitat fragmentation occurring in the Terminalia forest and the agricultural field than in areas naturally grown with sago. In earlier studies,

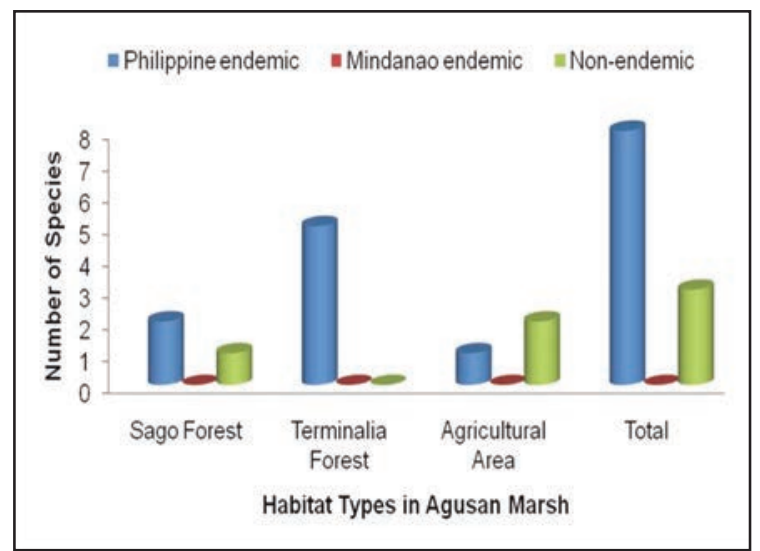

Figure13. Philippine endemics and non-endemics in sago forest, Terminalia forest, and agricultural area, Agusan wetlands, Bunawan, Agusan del Sur, Mindanao, Philippines.

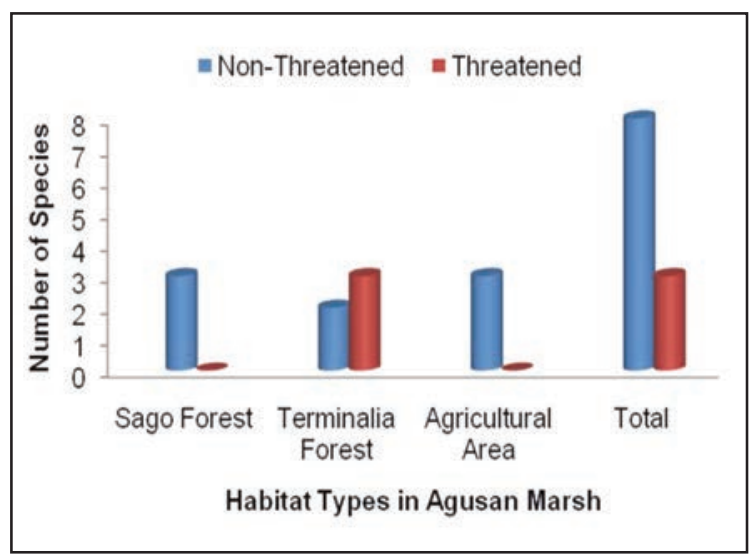

Figure 14. Threatened and non-threatened anurans in sago forest, Terminalia forest, and agricultural area, Agusan wetlands, Bunawan, Agusan del Sur, Mindanao, Philippines.

which began in 2003 (Ibanez \& Bastian, 2004), 12 species were found and assigned to five families and 11 genera. Among them, there were three vulnerable species (Ansonia muelleri, Philautus acutirostris, and Megophrys stejnegeri) and a threatened species (Limnonectes magnus) documented.

\section{CONCLUSIONS}

Indeed, the Agusan Marsh Willdife Sanctuary harbors anurans that are good biological indicators of habitat disturbance. Anurans exhibited high di- 
versity, endemisms, and threatened status in the Terminalia and the sago forests. Naturally grown sago stands ultimately serve as a habitat for more endemic anurans. The aquatic and arboreal species are highly habitat specific. Therefore, the sago stands harbor endemic and unique species and utilizing this habitat for reproduction and survival is the key to retaining biodiversity in the Agusan marsh.

\section{ACKNOWLEDGMENTS}

We would like to thank the Philippine Council for Advance Science and Technology Research and Development (PCASTRD) - Department of Science and Technology (DOST) for the funding of this research. We would also like to thank the Department of Environment and Natural Resources (DENR), Protected Areas Management Bureau (PAMB), Local Government Units (LGU's), and Indigenous People (IP) for the collection permit and support.

\section{REFERENCES}

Alcala A., 1982. Guide to Philippine flora and fauna. Amphibians and Reptiles. Natural Resources Management Center and University of the Philippines, pp. $1-46$.

Ates F.B., Relox R.E., Leano E.P., Bastian S.T.J.R., Sumile E.B. \& Amoroso V.B., 2008. Inventory of mammals, birds, reptiles and amphibians in Mt. Hamigiutan and its environs, Davao Oriental, Mindanao Island. In: Proceedings 17th Annual Philippine Biodiversity Symposium. Human Population Density: Impacts on Biodiversity. Wildlife Conservation Society of the Philippines (WCSP). April 14-17, 2008. Visayas State University, Baybay, Leyte, 38 pp.

Brown R., Diesmos A. \& Alcala A., 2008. An Evolutionary Classification of Philippine Amphibians and its Impact on Conservation Priorities. 17th Annual Philippine Biodiversity Symposium. Human Population Density: Impacts on Biodiversity. Wildlife Conservation Society of the Philippines (WCSP). April 14-17, 2008. VSU, Baybay, Leyte, $13 \mathrm{pp}$.

Brown R.N. \& Gonzalez J.C., 2007. A new forest frog of the genus Platymantis (Amphibia: Anura: Ranidae) from the Bicol Peninsula of Luzon Island, Philippines. Copeia. American Society of Ichthyologists and Herpetologists, 2: 251-266.
Cabelin V.L.D., 2007. Amphibian diversity and abundance in Bunawan, Agusan del Sur. Undergraduate Thesis. University of the Philippines Mindanao.

Fabricante K.M.B. \& Nuneza O.M., 2008. Anuran species composition, distribution and conservation status in Mt. Sambilikan, Diwata range, Agusan del Sur. In: Proceedings 17th Annual Philippine Biodiversity Symposium. Human Population Density: Impacts on Biodiversity. Wildlife Conservation Society of the Philippines (WCSP). April 14-17, 2008. Visayas State University, Baybay, Leyte, 43 pp.

Flach M., 1997. Sago palm: Metroxylon sagu Rottb. Promoting the conservation and the use of underutilized and neglected crops 13 . International plant genetic resources institute, Rome, Italy, $76 \mathrm{pp}$.

Frazier S., 1999. RAMSAR sites database: A directory of wetlands of international Importance.<http:// www.wetlands.org/RDB/Ramsar_Dir/Philippines/PH 003D02.htm> Accessed 2003 August 25.

Ibanez J.C. \& Bastian S.T. Jr., 2004. Are sago palm Metroxylon sagu growths in Agusan Marsh Wildlife Sanctuary a critical habitat for endemic wildlife? A Project Terminal Report. Biological Sciences and Environmental Studies Department, University of the Philippines Mindanao, Tugbok District, Davao City, 34 pp. https://www.researchgate.net/publication/280698170

IUCN, 2017. The IUCN Red List of Threatened Species. Version 2017-3. http://www.iucnredlist.org.

Mason P., 2000. Varied and versatile sago palm. http://www.vims.edu/ccrm/vwr/VWR-2000-summer.pdf. Accessed 2004 December 10.

Palafox D.B., 2006. A preliminary study on the gut contents of anurans in Terminalia Forest: Sitio Kaliloan, Barangay Poblacion, Bunawan, Agusan del Sur. Undergraduate Thesis. University of the Philippines Mindanao.

RAMSAR SITES DATABASE, 2003. A directory of wetlands of international importance. Retrieved January 18, 2003 from the World Wide Web: http://www. wetlands.org.

Rovillos K.P., Faldas S.L., Ates F.B. \& Relox R.E., 2008. Herpetofaunal diversity in Brgy. Lake Lahit, Municipality of Lake Sebu, South Cotabato, Mindanao. In Proceedings: 17th Annual Philippine Biodiversity Symposium. Human Population Density: Impacts on Biodiversity. Wildlife Conservation Society of the Philippines (WCSP). April 14-17, 2008. Visayas State University, Baybay, Leyte, 50 pp.

Taylor E.H., 1923. Addition to the herpetological fauna of the Philippine Islands. III. Philippine Journal of Science, 22: 515-557. 
Taylor E.H., 1925. Additions to the Herpetological Fauna of the Philippines, IV. Philippine Journal Science, 26: 97-111.
Yepsen R.B. Jr. (Ed.), 1984. The Encyclopedia of Natural Insect \& Disease Control. Rev. ed. Rodale Press, Emmaus, PA, pp. 267-271. 